Strategi Pengajaran Speaking Bagi Para Pembelajar Bahasa Inggris Berkarakteristik Introvert

M. Arif Rahman Hakim

\title{
I. STRATEGI PENGAJARAN SPEAKING BAGI PARA PEMBELAJAR BAHASA INGGRIS BERKARAKTERISTIK INTROVERT
}

\author{
M. Arif Rahman Hakim \\ Institut Agama Islam Negeri (IAIN) Bengkulu \\ E-mail : arifelsiradj90@iainbengkulu.ac.id
}

\begin{abstract}
Abstrak
Karakteristik dan kepribadian siswa dapat mempengaruhi kemampuan mereka untuk berkomunikasi. Beberapa ahli menyatakan bahwa dua karakter utama siswa dalam pembelajaran bahasa, yaitu ekstrovert dan introvert, yang mana karakter tersebut saling bertentangan. Oleh karena itu, para pengajar disarankan untuk mengetahui karakter siswanya, karena dengan mengetahui kepribadian mereka, para pengajar akan dapat memilih strategi pembelajaran yang tepat untuk diterapkan pada proses belajar mengajar di kelas mereka. Penelitian ini bertujuan untuk memberikan deskripsi tentang proses belajar mengajar dan strategi yang diterapkan oleh para pengajar bahasa Inggris kepada para siswa yang memiliki karakteristik kepribadian introvert di kelas speaking. Metode penelitian yang digunakan dalam penelitian ini adalah pendekatan kualitatif yaitu wawancara semi-terstruktur dan didukung oleh pengamatan pada proses belajar mengajar yang dilakukan oleh peneliti. Hasil penelitian ini menyimpulkan bahwa penggunaan metode pembelajaran kooperatif dapat menjadi solusi untuk kelas speaking yang didominasi oleh para siswa dengan karakteristik introvert.
\end{abstract}

Kata Kunci: speaking, karakteristik introvert, strategi pengajaran.

\begin{abstract}
Characteristics and personality of students can influence their ability to communicate. Some experts state that the two main characters of students in language learning, namely extroverts and introverts, which are conflicting characters. Therefore, the teachers are advised to know the character of their students, because by knowing their personalities, the teachers will be able to choose the right learning strategies to be applied to the teaching and learning process in their class. This study aims to give a description of the teaching and learning process and the strategies applied by English teachers to students who have introverted personality characteristics in speaking class. The research method used in this study is a qualitative approach that is semi-structured interviews and supported by observations in the teaching and learning process that has done by the researcher. The results of this study concluded that the use of cooperative learning methods could be a solution for speaking classes dominated by students with introverted characteristics.
\end{abstract}

Keywords: speaking, introvert characteristic, teaching strategy

\section{PENDAHULUAN}

Dominasi Bahasa Inggris secara akademik ataupun dibidang lainnya terutama di zaman revolusi industri 4.0 sudah tak bisa dipungkiri. Hingga detik ini, bahasa Inggris masih digunakan sebagai bahasa diplomasi, bisnis, pariwisata, pendidikan, ilmu pengetahuan, hiburan, teknologi komputer dan media di tingkat internasional. Selain itu, bahasa Inggris juga seringkali digunakan sebagai bahasa pengantar dalam pengembangan dibidang komunikasi, teknologi, internet, dan perangkat lunak yang mana hal- hal tersebut merupakan kebutuhan utama di era milenial saat ini. Namun sejak beberapa tahun ini, penggunaan Bahasa Inggris menjadi semakin popular digunakan di Indonesia dan seakan telah menjadi kebutuhan premier bagi masyarakat di Negara ini.

Jika dikaitkan pada keutamaan penguasaan bahasa asing dari segi agama Islam, hal ini sudah terjadi sejak zaman Nabi Muhammad Saw. Pentingnya penguasaan bahasa asing ini dijelaskan Hakim yang dikutip dari hadits yang diriwayatkan oleh Imam Ahmad, Abu Dawud dan At-Turmuzi Nomor 2933 bahwa Zaid bin Tsabit pernah diperintahkan oleh Rasulullah untuk belajar bahasa bangsa Yahudi karena Rasulullah mempunyai keinginan untuk mengirim surat pada mereka dan pada akhirnya Zaid bin Tsabit memulai untuk mempelajari bahasa tersebut selama 16 hari hingga menguasainya. Sahabat Rasulullah tersebut lalu menceritakan, "setelah aku menguasai bahasa bangsa Yahudi, lalu Rasulullah bermaksud untuk mengirim surat kepada orang bangsa Yahudi, sehingga aku menuliskannya pada mereka, dan jika mereka mengirim surat kepada Nabi Aku akan membacakannya untuknya. Dalam hadits lain, Nabi kemudian mengirim Zaid bin Thabit untuk pelajari bahasa Syiria (Hakim, 2017). Makna yang dapat kita ambil dari hadits tersebut 
adalah tentang pentingnya penguasaan bahasa asingsalah satunya Bahasa Inggris karena merupakan kebutuhan umat Islam mengingat keterkaitan bahasa Inggris dengan teknologi, pendidikan dan peradaban.

Dalam konteks pengembangan peran bahasa Inggris di Indonesia, kemampuan speaking tampaknya menjadi sasaran utama bagi bagi para pembelajar Bahasa Inggris baik itu ditingkat sekolah, universitas maupun pembelajar umum. Hal ini juga tidak lepas keterkaitannya dengan dengan pelaksanaan ASEAN free trade area. Itulah sebabnya Bahasa Inggris ditetapkan sebagai salah satu mata pelajaran utama di dalam kurikulum sekolah di Indonesia (Sudrajat, 2011). Menurut Thornbury (2005) speaking adalah salah satu komponen penting dari kurikulum pembelajaran Bahasa Inggris karena akan menjadi dasar dalam pertumbuhan keterampilan lisan lainnya dan memiliki keterkaitan yang erat dengan kemampuan listening. Oleh karena itu, keterampilan speaking memungkinkan para siswa untuk menciptakan hubungan antara apa yang mereka ketahui dan apa yang mereka pelajari, sedangkan listening nantinya akan membantu para pembelajar dalam memperoleh pengetahuan dan menggali ide-ide baru.

Pada dasarnya terdapat dua model kemampuan speaking, yaitu yang dapat disampaikan secara langsung tanpa perencanaan yang baik atau menggunakan makna gramatikal yang tersusun rapi dan dengan perencanaan yang baik meskipun tujuannya adalah berkomunikasi secara lisan dengan seseorang. Dalam hal ini, kepercayaan diri dan antusiasme siswa dalam berbicara adalah faktor yang paling penting dalam pengembangaan keterampilan atau komunikasi lisan para siswa. Namun, dalam konteks pembelajaran Bahasa Inggris di negara yang mempelajari Bahasa Inggris sebagai bahasa asing (EFL) seperti di Indonesia, siswa cenderung memiliki masalah dengan keterbatasan kosakata (vocabulary), ketepatan pengucapan (pronunciation), dan juga keterbatasan lingkungan (environment). Faktor-faktor tersebut terkadang membuat mereka malas untuk belajar Bahasa Inggris dan mereka cenderung jarang menggunakan bahasa Inggris di lingkungan mereka seperti di dalam kelas, kerja, sekolah, lingkungan tempat mereka tinggal ataupun dirumah.

Terdapat beberapa faktor yang mempengaruhi kinerja speaking para siswa seperti; kecemasan, gugup, dan tidak percaya diri (Brown, 2000). Selain itu, Brown juga menyatakan bahwa karakteristik siswa juga mempengaruhi kinerja speaking mereka. Selanjutnya, terkait dengan tipe pembelajar, Brown juga mengklasifikasikan karakteristik kepribadian seseorang menjadi 2 jenis: ekstrovert dan introvert. Seseorang yang ekstrovert adalah mereka yang memiliki ketertarikan dengan keramaian dan menganggap itu sebagai pengisian ulang tenaganya. Sebaliknya, seseorang yang introvert dianggap sebagai sosok yang lebih tenang dan pendiam dengan kecenderungan ke arah sosok yang tertutup. Sejalan dengan Friedman \& Schustack menjelaskan ada dua karakter utama dalam diri seseorang. Mereka adalah ekstrovert dan introvert. Kedua karakter ini saling bertentangan satu sama lain karena akan berpengaruh pada kompetensi komunikasi seseorang terutama dalam hal motivasi dan egoisme (Friedman dan Schustack, 2001)

Busch seperti dikutip dalam Brown (2000) menyebutkan bahwa mereka yang memiliki karakter ekstrovert akan bersikap kurang sensitif terhadap rangsangan daripada mereka yang introvert. Secara emperis, studi tersebut menunjukkan bahwa kebanyakan pelajar EFL yang berkarakteristik ekstrovert memiliki pengucapan (pronunciation) bahasa Inggris lebih baik daripada mereka yang introvert, sementara mereka yang introvert cenderung memiliki prestasi yang lebih tinggi pada kemampuan membacanya (reading) dan tata bahasa (grammar).

Sejalan dengan temuan empiris dan literatur terkait, investigasi dan pengamatan penulis pada beberapa kelas yang didominasi oleh siswa berkarakteristik introvert, menunjukkan bahwa mereka yang berkarakteristik introvert seringkali merasa malu dan berbicara lebih sedikit selama kegiatan di kelas. Sejalan dengan kenyataan tersebut, Rauch (2003) menyatakan bahwa sekitar seperempat orang di dunia adalah introvert. Dia juga menjelaskan bahwa seorang introvert selalu perlu untuk menghentikan interaksi sosialnya (turn-off) dan mengisi ulang (recharge) setelah melakukan kontak sosial dengan orang lain. Ini bukan berarti mereka merupakan anti-sosial, sebagai tanda depresi dan tidak pula disebut sebagi meditasi. Untuk mereka yang berkarakteristik introvert, menyendiri dengan pikiran mereka sama menyegarkannya selayaknya tidur dan sama bergizinya selayaknya makan.

Untuk mendapatkan keterangan yang mendalam dari perilaku siswa yang berkarakteristik introvert dalam proses belajar Bahasa Inggris dan aktivitasnya di kelas, penulis juga mewawancarai 5 orang guru Bahasa Inggris di English Academy Bengkulu yang mengajar kelas speaking dan juga 10 orang siswa yang bergabung dikelas speaking dengan cara dipilih secara acak. English Academy Bengkulu adalah lembaga yang bergerak dibidang kursus bahasa Inggris, konsultan pendidikan, jasa penelitian berbahasa Inggris, dan penerjemah yang saat ini memiliki lebih dari 200 siswa aktif. Lembaga ini diakui dan terdaftar pada bagian pendidikan luar sekolah oleh Kementerian Pendidikan Nasional Indonesia. Berdasarkan hasil wawancara pada observasi awal kepada beberapa pengajar terkait, penulis mendapatkan informasi bahwa siswa berkarakteristik introvert cenderung mendapatkan prestasi yang lebih rendah di sekolah jika dibandingkan para siswa yang terindikasi memiliki karakteristik ekstrovert dalam pelajaran speaking. Mereka juga jarang berbagi cerita dengan teman sekelasnya, dan mereka lebih sering mengerjakan tugas yang diberikan oleh para guru secara individu. Fakta ini membuat kelas menjadi tidak aktif sehingga menyebabkan para pengajar harus berpikir keras untuk mencari solusi dari masalah ini.

Berdasarkan data empiris dan literatur, penulis berasumsi bahwa terdapat beberapa masalah yang kerap dihadapi oleh para pengajar Bahasa Inggris di Indonesia 
dalam mengajar speaking dikarenakan terdapat perbedaan prestasi akademik yang sering didapatkan secara signifikan antara siswa yang berkarakteristik introvert dan ekstrovert terutama dalam hal pembelajaran speaking, lebih khususnya lagi terkait kemampuan eksplorasi topik berbicara maupun keaktifan serta dominasi didalam kelas selama proses belajar mengajar (Nurmayasari dan Rahmawati, 2016).

Disisi lain, penulis juga percaya bahwa para pengajar yang memang sudah berpengalaman dalam pengajaran speaking pasti memiliki strategi tertentu yang diterapkan dalam proses pengajaran pada materi yang bersinggungan dengan kemampuan speaking, terutama ketika para pengajar tersebut mendapatkan suatu masalah di kelas yang mereka ajar dan problem tersebut erat kaitannya terhadap perbedaan karakteristik sehingga berpengaruh pada pencapaian akademik peserta didiknya. Karena berdasarkan observasi awal penulis di lembaga kursus English Academy Bengkulu, penulis mendapatkan informasi bahwa kebanyakan siswa yang mengambil kelas speaking dilembaga mereka kemungkinan besar adalah siswa yang memiliki karakteristik introvert yang mana para siswa tersebut berkeinginan untuk meningkatkan kemampuan speaking mereka, terutama dalam hal kepercayaan diri. Itulah sebabnya, penulis merasa tertarik untuk menyelidiki tantangan yang dihadapi dan strategi apa yang diterapkan oleh para pengajar Bahasa Inggris tersebut di lembaga kursus English Academy Bengkulu dalam mengajar dikelas speaking yang didominasi oleh siswa introvert. $\mathrm{n}$

Dalam pengumpulan data, penulis mewawancarai dan mengamati kelas speaking yang diajarkan oleh para pengajar yang sudah memiliki pengalaman dalam bidang pengajaran Bahasa Inggris, terutama di bidang speaking. Para pengajar yang berpengalaman tersebut dalam hal ini dikelompokkan berdasarkan lamanya mengajar, dan indikatornya adalah telah berpengalaman selama lebih dari 5 tahun mengajar di kelas Speaking. Dalam penelitian ini, penulis selalu hadir dikelas sebelum pelajaan dimulai serta mengikuti seluruh prosesi belajar mengajar pada topik speaking tersebut hingga kelas itu selesai. Dalam kesempatan ini, penulis sepenuhnya hanya sebagai pengamat. Selain melakukan observasi langsung kekelas speaking di English Academy Bengkulu sebanyak lima belas kali di lima kelas yang berbeda, penulis juga melaksanakan proses pengkajian beberapa literatur terkait strategi mengajar yang digunakan oleh para guru tersebut.

Salah satu cara untuk berkomunikasi dengan baik dalam Bahasa Inggris adalah melalui penguasaan kemampuan speaking. Jika kita dapat membuat pendengar mengerti dengan baik terkait apa yang kita maksudkan, maka dikatakan bahwa kita sudah dapat berkomunikasi dengan baik. Dalam hal ini, Harmer (2007) menyatakan bahwa keterampilan speaking adalah kegiatan keterampilan produktif (productive skill). Ini adalah cara di mana bahasa diwujudkan dalam fungsi komunikasi. Ini berarti bahwa dalam proses belajar mengajar dikelas speaking, siswa memang harus diberikan kesempatan berbicara sebanyak mungkin dan tugas para guru adalah memberikan kesempatan bagi para siswa untuk berkomunikasi satu sama lain sebanyak mungkin agar dapat terciptanya suasana pembelajaran yang aktif dan kreatif karena akan berdampak pada pengembangan ide dan topik para siswa dalam proses pembelajaran speaking. Dalam hal ini para guru juga harus dapat memotivasi dan menstimulus siswa- siswinya agar dapat memperluas imajinasi mereka saat melakukan latihan.

Kemampuan Speaking juga merupakan salah satu cara untuk mengkomunikasikan ide-ide dan pesan secara lisan. Untuk memungkinkan siswa dalam berkomunikasi, para guru perlu menerapkan bahasa dalam komunikasi yang nyata. Menurut Bilbrough (2007), speaking adalah sebuah kemampuan dengan tujuan mengutarakan maksud yang diakui dan nantinya lawan bicara akan memproses pernyataan pembicara dengan tujuan mengenali maksud-maksud itu. Namun Brown, Gillian dan Yule (1999) menyatakan bahwa topik yang dibicarakan pada pelajaran speaking juga dapat tergantung pada kompleksitas informasi yang akan dikomunikasikan, namun nyatanya para pembelajar seringkali menemukan kesulitan untuk memperjelas terkait apa yang ingin mereka katakan. Namus sejatinya Speaking adalah sebuah cara untuk mengekspresikan pikiran dan ide kita. Pernyataan ini didukung oleh Collie \& Stephen (2006), mereka menyatakan bahwa speaking disebut sebagai komunikasi lisan atau ekspresi pikiran, ide, dan perasaan dalam bentuk perkataan. Bahasa Inggris sebagai bahasa asing, umumnya sebagian besar siswa memiliki beberapa masalah dalam proses belajar.

Menurut Al- Jarf (2012), speaking adalah sebuah kemampuan oral untuk mencapai tujuan pragmatis melalui wacana interaktif dengan pembicara lain dari bahasa yang sama. Speaking sebagai salah satu bentuk komunikasi untuk berinteraksi dengan orang-orang secara lisan. Dalam speaking orang-orang diharapkan untuk dapat mengkomunikasikan ide-ide, perasaan, dan pendapat mereka. Tujuannya adalah agar peserta dapat menciptakan interaksi sosial yang nyaman dan berkomunikasi dengan baik. Sejalan dengan pernyataan tersebut, Hakim (2015) menyatakan pada umumnya para siswa di Indonesia enggan berbicara bahasa Inggris karena memiliki permasalahan kurangnya perbendaharaan kata dalam Bahasa Inggris (vocabularies) dan frase-frase (phrases) untuk mengekspresikan ide-ide mereka dalam bahasa Inggris.

Berdasarkan beberapa penjelasan dari para ahli diatas, penulis mengklasifikasikan beberapa faktor yang kemungkinan besar dirasakan oleh para peserta didik ketika mereka belajar ataupun ketika mereka mengaplikasikan speaking bahasa Inggris.

1. Kecemasan

Salah satu masalah utama dalam belajar bahasa Inggris adalah perasaan cemas yang dirasakan ketika akan mulai berbicara dalam Bahasa Inggris. Harmer (2007) mengatakan siswa akan menunjukkan kecemasan yang luar biasa ketika mereka diminta untuk menggunakan bahasa baru dalam kegiatan seperti laporan lisan, sandiwara, 
drama, atau ujian speaking dan listening. Berbicara di depan orang lain adalah hal yang paling sering menimbulkan kecemasan. Dia juga menyatakan bahwa penting untuk membangun suasana kelas yang santai, sehingga dapat membantu siswa untuk berpikir bahwa kelas adalah laboratorium di mana mereka bisa bereksperimen untuk mengambil risiko dari sebuah pembelajaran bahasa. Kecemasan dalam speaking biasanya muncul karena beberapa alasan yang dirasakan beberapa siswa yaitu merasa takut akan membuat kesalahan ketika proses belajar. Terkait hal tersebut, terdapat sebuah pepatah yang seperti sudah menjadi mindset para siswa yang berbunyi "Anda adalah apa yang Anda bicarakan", oleh karena itu, para siswa kebanyakan merasa enggan untuk dihakimi oleh sesama siswa. Hal ini sama seperti apa yang Tillit dan Bruder (1999) bahwa para siswa seringkali terhambat dalam percobaan untuk mengatakan tentang suatu hal dalam bahasa asing di dalam kelas. Salah satu penyebab timbulnya kekhawatiran akan membuat kesalahan adalah para siswa seringkali enggan untuk berpartisipasi dalam kegiatan speaking tersebut, karena kebanyakan dari mereka sadar diri dan tidak ingin membuat kesalahan atau terlihat bodoh di depan teman-temannya. Para siswa benarbenar takut akan kegagalannya, menjadi bahan tertawaan, dan juga ejekan bagi para siswa yang lain.

2. Gugup

Sementara itu, meskipun beberapa siswa memiliki banyak perbendaharaan kosa kata dalam Bahasa Inggris (vocabularies) dan tata bahasa yang baik (grammar), kadang-kadang mereka masih memiliki rasa gugup. Kondisi ini bisa jadi berasal dari siswa lain yang memiliki kemampuan berbahasa Inggris lebih lancar. Seringkali para siswa yang memiliki kemampuan speaking dengan lancar akan terlihat lebih dominan di dalam kelas. Sehingga hal tersebut dapat membuat para siswa lain merasa enggan untuk berbicara bahasa Inggris. Mereka memilih untuk diam karena kemungkinan besar mereka akan merasa gugup jika tetap memaksakan untuk berbicara.

3. Tidak Percaya Diri

Beberapa siswa tidak percaya diri ketika mereka berbicara Bahasa Inggris. Perasaan ini lebih sering didasari oleh kesadaran kemampuan mereka dalam berbahasa Inggris. Siswa yang memiliki sifat ini berpikir bahwa bahasa Inggris yang mereka miliki tidak sebagus para siswa yang lain. Mereka merasa siswa lain dapat berbicara bahasa Inggris lebih baik dari mereka. Mereka khawatir pada saat mereka berbicara bahasa Inggris, teman-teman mereka akan meremehkan mereka.

Brown menyatakan bahwa ada beberapa faktor yang mempengaruhi kinerja speaking dari para pembelajar seperti kecemasan, gugup, dan tidak percaya diri. Selain itu, ia juga menyatakan bahwa karakteristik siswa juga akan mempengaruhi kemampuan speaking mereka (2000). Selanjutnya, Brown mengklasifikasikan karakteristik kepribadian seseorang menjadi 2 jenis: ekstrovert dan introvert. Seseorang yang ekstrovert adalah mereka yang suka berteman, seseorang yang "life of the party". Ekstrovert adalah sejauh mana seseorang memiliki kebutuhan yang mendalam untuk menerima pesona ego, harga diri, dan rasa keutuhan dari orang lain sebagai lawan untuk menerima penegasan itu dalam diri sendiri. Mereka yang ekstrovert benar-benar membutuhkan orang lain untuk merasa "baik". Tapi mereka tidak selalu berkeinginan keras dan terkesan banyak bicara. Sebaliknya, seseorang yang introvert dianggap sebagai sosok yang tenang dan pendiam dengan kecenderungan ke arah sosok yang tertutup. Mereka mungkin relatif pemalu namun masih perlu penegasan dari orang lain. Introvert, di sisi lain, adalah sejauh mana seseorang membangun rasa keutuhan dan pemenuhan terlepas dari refleksi diri ini dari orang lain. Bertentangan dengan stereotip kita, mereka yang introvert dapat memiliki kekuatan batin sebagai karakter yang tidak dimiliki oleh mereka yang ekstrovert.

Di sisi lain, Jung di dalam Friedman dan Schustack (2001) menjelaskan terdapat dua karakter utama dalam diri seseorang. Mereka adalah ekstrovert dan introvert. Kedua istilah ini saling bertentangan. Mereka mempengaruhi kompetensi komunikasi seseorang karena motivasi dan egoisme antara ekstrovert dan introvert memang berbeda. Lebih lanjut ia juga menyatakan bahwa seseorang yang memiliki karakteristik ekstrovert akan memberikan lebih banyak tanggapan atau perasaan diluar energi psikologi, misalnya, ia akan fokus atau melakukan aktivitas di luar. Umumnya orang ekstrovert lebih mudah untuk mendapatkan teman-teman, terlihat berusaha menonjolkan diri dalam banyak hal, mudah dipengaruhi oleh emosional orang lain. Sementara itu, seseorang yang berkarakteristik introvert lebih cenderung fokus pada dirinya sendiri. Umumnya seseorang yang mempunyai karakteristik introvert merasa bahwa ia tampaknya sendirian, dan ketika mereka memiliki masalah, mereka akan lebih memilih memecahkan masalah itu sendiri dibandingkan berbagi dengan orang lain. Oleh karena itu, mereka yang introvert terlihat seakan tidak peduli dengan orang lain dan mereka terlihat pendiam. Jadi, menurut Jung, kepribadian juga dapat mempengaruhi motivasi dan egoisme dalam komunikasi yang nyata.

Sunatyo (2008) mendukung teori di atas dengan megatakan bahwa karakteristik orang-orang introvert adalah orang yang tertutup dan mereka tidak begitu suka berlama- lama dengan orang lain, sering merasa canggung dengan orang-orang baru, sulit untuk mengungkapkan ide mereka di depan orang, dan tidak benar-benar ingin menunjukkan diri mereka kepada publik. Kadang, mereka merasa takut untuk membuka percakapan dengan orang lain dan lebih mudah tersinggung, terutama tentang lelucon yang berhubungan dengan mereka. Mereka juga selalu merasa tidak percaya diri. 
Myers-Briggs dalam Brown (2000) mengklasifikasikan karakter dari seorang introvert dalam tabel berikut:

Tabel 1. Klasifikasi Kepribadian Introvert oleh MyersBriggs

\begin{tabular}{cc}
\hline No & Klasifikasi Karakter Introvert \\
1 & Territoriality \\
2 & Concentration \\
3 & Internal \\
4 & Depth \\
5 & Intensive \\
6 & Limited relationship \\
7 & Conservation of energies \\
8 & Interest in internal reaction \\
\hline
\end{tabular}

Terkait dengan penjelasan di atas, Busch di dalam Brown (2008) pada studi komprehensifnya tentang ekstrovert, ia menggali hubungan antara introvert dan ekstrovert terhadap kemampuan bahasa Inggris pada pelajar bahasa Inggris dewasa di Jepang. Dia membuat hipotesis bahwa siswa ekstrovert (yang diukur dengan persediaan kepribadian standar) akan lebih mahir kemampuan Bahasa Inggrisnya dari mereka yang introvert. Namun pada akhir penelitiannya, hipotesis tersebut tidak didukung oleh hasil temuannya. Bahkan yang lebih mengejutkan baginya, para siswa yang berkarakteristik introvert secara signifikan mempunyai kemampuan yang lebih baik daripada mereka yang memiliki karakteristik ekstrovert dalam hal pengucapan (pronunciation).

Dalam hal ini, hasil kajian Olson dan Horgenhahn didalam Maynard (2013) menyatakan bahwa siswa introvert adalah orang-orang yang membutuhkan ruang pribadi untuk mengisi bahan bakar (refuel), yang energi utamanya tidak lagi berasal dari kegiatan eksternal, dan yang biasanya perlu waktu untuk merenung dan berpikir sebelum mereka berbicara. Siswa introvert, di sisi lain, diberi energi oleh dunia internal dengan ideide, kesan, dan emosi. Berbeda dengan stereotipe kita terhadap seorang siswa introvert, mereka tidak selalu diam atau suka menyendiri, tapi fokus mereka adalah di dalam fikiran mereka. Mereka membutuhkan tempat yang tenang, reflektif di mana mereka dapat memikirkan semuanya dan mengisi ulang (recharge) diri sendiri. Berdasarkan pengamatan penulis selama di kelas, penulis melihat jelas keterkaitan antara teori berkenaan dengan para siswa introvert dan menyandingkannya dengan keadaan para siswa English Academy Bengkulu yang menjadi responden dan memang pada nyatanya terdapat banyak kesamaan. Dalam kesempatan ini, penulis juga berkesimpulan bahwa para guru adalah kunci utama dalam menciptakan situasi yang nyaman di dalam kelas, terutama ketika terdapat siswa introvert di kelas mereka.

Menurut Tarone di dalam Ya (2007), sebuah strategi pembelajaran bahasa merupakan satu upaya untuk mengembangkan kompetensi linguistik dan sosiolinguistik di dalam pembelajaran sebuah bahasa dan contoh strategi pembelajaran bahasa meliputi penghafalan kosakata baru, memulai percakapan dengan penutur asli, dan membuat kesimpulan.
Keterampilan strategi belajar yang baik akan fokus pada peserta didik yang berusaha untuk menjadi komunikator yang terampil dan melibatkan berbagai jenis kegiatan, seperti strategi untuk membaca, menulis, belajar dan mengingat informasi, berinteraksi dengan orang lain secara efektif, belajar untuk mengikuti sebuah tes, dan memotivasi diri untuk belajar.

Meskipun gaya belajar perseptual adalah gaya belajar yang paling terkenal bagi kalangan guru, mereka sebenarnya hanyalah salah satu dari berbagai jenis gaya belajar. Selain itu, Murray dan Christinson juga mengklasifikasikan beberapa gaya belajar sesuai dengan tipe dari para siswa (2010).

\section{Tabel 2. Gaya Belajar Siswa oleh Murray \& Christison}

\begin{tabular}{ccc}
\hline \multicolumn{3}{c}{ Learning Styles in the Classroom } \\
\hline Cognitive Styles & Sensory Styles & $\begin{array}{c}\text { Personality } \\
\text { Styles }\end{array}$ \\
\hline $\begin{array}{c}\text { Field dependent / Field } \\
\text { Independent }\end{array}$ & $\begin{array}{c}\text { Perceptual: } \\
\text { Visual, auditory, } \\
\text { tactile, kinesthetic }\end{array}$ & $\begin{array}{c}\text { Tolerance of } \\
\text { ambiguity }\end{array}$ \\
\end{tabular}

\begin{tabular}{ccc} 
& $\begin{array}{c}\text { Environmental: } \\
\text { Physical and } \\
\text { Reflective / Impulsive }\end{array}$ & $\begin{array}{c}\text { Right and left } \\
\text { semisphere } \\
\text { dominance }\end{array}$ \\
\hline
\end{tabular}

Pembelajaran model "field independent" adalah gaya belajar yang lebih lebih condong bekerja dengan informasi dalam bentuk langkah demi langkah dan merupakan bentuk gaya pembelajaran yang paling efektif karena informasi akan disajikan secara berurutan. Para siswa dengan model belajar seperti ini akan lebih suka bekerja dengan rincian terlebih dahulu dan untuk membuat gambaran besar dari rincian tersebut. Peserta didik "analytic" tidak hanya lebih suka bekerja sendiri, tetapi mereka juga lebih memilih untuk bekerja pada kecepatan mereka sendiri. Peserta didik dengan tipe pembelajaran seperti ini akan menikmati kesempatan belajar secara otonom dan mandiri, seperti tugas mandiri dan program pembelajaran bahasa mandiri walaupun pada faktanya secara umum, para peserta didik akan merasa bekerja lebih efektif dalam sebuah kelompok dan lebih memilih kelas di mana guru memberikan tugas secara berpasangan dan berkelompok untuk memproses informasi baru. Terakhir adalah peserta didik "reflective" yang selalu ingin diberi waktu untuk mempertimbangkan informasi baru terlebih dahulu sebelum menjawab. Sebagai pembelajar bahasa, mereka bukanlah tipe yang pengambil risiko; akibatnya, mereka sering enggan untuk berkontribusi di dalam kelas.

Terdapat dua jenis gaya belajar sensorik; perseptual dan berdasarkan lingkungan. Gaya belajar perseptual meliputi visual, auditori, kinestetik, dan taktis. Pelajar visual lebih suka bekerja dengan bahasa tertulis atau menerima penguatan konsep visual, contohnya dalam 
bentuk grafik, gambar dan tabel. Pelajar auditori lebih memilih untuk menerima informasi baru dengan mendengarkan dan dengan berbicara dan berinteraksi dengan guru dan peserta didik lainnya di dalam kelas. Gaya pelajar kinestetik akan lebih efektif ketika terdapat gerakan yang terkait dengan pembelajaran dan bertentangan dengan kegiatan yang memerlukan peserta didik untuk hanya duduk di meja. Peserta didik taktis lebih memilih untuk belajar ketika ada kesempatan untuk menggunakan sumber-sumber manipulatif, seperti contohnya handout kartu flash.

Jenis lain dari gaya belajar sensorik adalah lebih pada pemanfaatan lingkungan. Jenis pertama dari gaya belajar lingkungan adalah secara fisik. Secara fisik, peserta didik akan lebih sensitif terhadap karakteristik fisik disekitar lingkungan mereka, seperti apakah kelas memiliki cahaya buatan atau alami, apakah suhu terlalu panas atau dingin, dan apakah meja atau kursi mereka nyaman atau tidak. Jenis kedua adalah pelajar sosiologis. Individu di lingkungan mereka akan secara langsung berpengaruh terhadap peserta didik sosiologis ini, akibatnya, mereka akan peka terhadap pengaturan ruang kelas, seperti apakah kursi dan meja berada di baris lurus atau membentuk kelompok-kelompok kecil, karena mereka merasa bahwa bentuk pengaturan suatu ruang akan mempengaruhi interaksi mereka terhadap orang lain.

Toleransi ambiguitas mengacu pada seberapa nyaman pelajar dengan ketidakpastian bahasa pada umumnya. Beberapa siswa melakukannya dengan baik dalam situasi di mana terdapat beberapa kemungkinan jawaban (terkadang juga mereka lebih memilih satu jawaban yang mereka anggap paling benar). Guru yang menyediakan para pelajar dengan kedua pilihan yang disebutkan diatas berarti sedang menangani gaya belajar ini. Dominasi belahan otak kanan dan kiri mungkin merupakan jenis kepribadian lain dari gaya belajar ini. Peserta didik yang didominasi oleh otak kiri cenderung lebih visual, analitis, reflektif, dan mandiri, sementara peserta didik yang lebih dominan pada otak kanan cenderung lebih ingin mendengar, berpandangan luas, impulsif, dan interaktif. Maka dari itu, penulis berpendapat bahwa para guru yang dapat memvariasikan aktivitas didalam kelasnya akan lebih berhasil dalam mendekati kedua jenis peserta didik tersebut.

Guru atau pengajar merupakan komponen penting yang mempengaruhi perkembangan siswa. Leo (2013) menyebutkan bahwa seorang guru adalah pendidik sekaligus ilmuwan profesional yang pekerjaan utamanya adalah mengubah, mengembangkan dan menyebarkan ilmu pengetahuan, teknologi dan seni melalui pendidikan, penelitian dan pengabdian kepada masyarakat; juga berpendidikan serta menunjukkan kinerja yang tinggi. Ide tersebut sebenarnya telah dinyatakan oleh Menteri Pendidikan Republik Indonesia yang pertama, Ki Hajar Dewantara yang menunjukkan tiga karakteristik penting dari seorang guru profesional. Namun saat ini sedikit sulit untuk menemukan guru atau dosen yang mampu memenuhi karakteristik ini. Karakteristik yang dimaksud adalah Ing ngarso sung tuladha yang bermakna di depan, guru menjadi model; Ing madya mangun karsa yang bermaksud di tengah, guru adalah seorang motivator; dan Tut wuri handayani yang berarti di belakang, guru adalah seorang pendukung (Wardani).

Di sisi lain, sikap guru sangatlah penting, karena akan berpengaruh dalam pengembangan pikiran dan bakat siswa. Dalam hal ini, Leo (2013) juga berpendapat bahwa sikap merupakan karakteristik yang sangat penting bagi seorang guru. Sikap positif merupakan aset besar untuk mengatasi semua masalah kehidupan dengan cara yang terbaik. Masalah tidak hanya sebagai etiket profesi mengajar, namun memiliki semangat yang tinggi dan mudah diingat untuk disampaikan kepada siswa kita.

Sikap profesional seorang guru sering tak terlihat tetapi pasti dirasakan oleh siswa. Harmer (2007) menyatakan bahwa guru yang baik akan mempersiapkan segala sesuatunya dengan baik. Dia senantiasa akan mempersiapkan pelajaran dan bahan ajar sebelum ia menghadapi para siswanya. Dia akan mengikuti alur seperti biasa dan siap untuk mengatur kegiatan yang dijadwalkan. Dia juga akan siap dengan pelajaran yang tidak berjalan sesuai dengan rencana karena ia akan memiliki cadangan rencana dan bersedia untuk mengubah rencananya jika memang diperlukan.

\section{METODE}

Metode penelitian yang digunakan dalam studi ini adalah pendekatan kualitatif dengan menggunakan wawancara semi-terstruktur. Jenis wawancara ini digunakan untuk pengumpulan data karena penulis merasa wawancara seperti ini lebih terbuka dan memberikan lebih banyak fleksibilitas dalam mengelola wawancara itu sendiri. Menurut Al-Nassar (2010), wawancara semi-terstruktur mengkonsolidasikan tidak hanya bagian dari wawancara terstruktur saja, namun juga wawancara yang tidak terstruktur, yang nantinya memungkinkan seorang penanya memberikan pertanyaan-pertanyaan yang memang sudah dirancang sebelumnya lalu digunakan dalam wawancara terstruktur, tapi dalam hal ini juga ia dapat mempertimbangkan kesempatan untuk memberikan pertanyaan diluar perencanaan selayaknya wawancara yang tidak terstruktur. Pada kajian ini, penulis memilih lima orang guru dan sepuluh orang siswa yang berasal dari kelas speaking di English Academy Bengkulu secara acak untuk melaksanakan proses wawancara 
setelah program kursus berlangsung di setiap pertemuan. Pertanyaan wawancara teah divalidasi oleh dua orang dosen (ahli) di bidang pengajaran bahasa Inggris dan studi kualitatif dari pusat bahasa Institut Agama Islam Negeri (IAIN) Bengkulu Indonesia. Dalam proses validasi tersebut, telah terjadi beberapa perubahan dan penyesuaian bentuk pertanyaan dari yang diajukan oleh penulis.

\section{HASIL DAN PEMBAHASAN}

Dalam penelitian ini, penulis mengamati dan mewawancarai lima orang guru bahasa Inggris di English Academy Bengkulu Indonesia yang telah berpengalaman mengajar Bahasa Inggris, termasuk pelajaran speaking selama lebih 5 tahun. Dalam proses pengamatan, para guru tersebut telah mengetahui beberapa siswa dikelasnya yang mereka telah yakini bahwa siswa- siswa tersebut mempunyai karakteristik introvert. Namun dalam proses belajar mengajar mereka tetap mencampur para siswa introvert tersebut bersama siswa- siswa yang lain. Para guru tersebut beranggapan bahwa karakteristik introvert bukanlah suatu hal yang diidentikkan dengan kelainan dalam belajar, namun itu hanya sebuah karakter belajar dari seorang siswa, sehingga cara terbaik adalah dengan membiarkan mereka tetap berinteraksi dengan temanteman sebayanya dikelas. Dalam melakukan observasi, penulis membuat catatan-catatan kecil terkait dengan beberapa hal yang dirasa penting bagi penelitian ini. Pengamatan dilakukan selama 15 kali pertemuan didalam 5 kelas speaking yang berbeda. Dalam melakukan observasi, penulis fokus pada bagaimana situasi dan aktivitas sebelum kelas dimulai, selama kelas berlangsung, apa masalah apa yang tampak dihadapi oleh para siswa introvert dan apa yang selanjutnya para guru tersebut lakukan.

Berdasarkan rangkuman hasil wawancara, penulis mendapatkan penjelasan bahwa masalah utama yang dihadapi oleh para guru tersebut adalah berkaitan dengan instrumen pengajaran yang meliputi materi dan silabus. Mereka menyatakan bahwa mereka perlu merancang dan memodifikasi sendiri bahan ajar yang didasarkan pada pendekatan ilmiah untuk memfasilitasi para siswa introvert agar dapat lebih aktif berperan aktif didalam kelas. Masalah berikutnya adalah motivasi siswa dalam untuk turut berperan dalam aktifitas- aktifitas dikelas yang dapat dikatakan sangat rendah dan sebagai solusinya, para guru tersebut memberi kesempatan sebanyak mungkin pada siswanya untuk berbicara meski dalam waktu yang sangat terbatas. Selanjutnya, dalam proses belajar mengajar, para guru juga harus bersikap seadil mungkin sehingga setiap siswa yang memiliki karakter introvert didalam kelasnya juga memiliki kesempatan yang sama dengan para siswa yang berkarakteristik extrovert dalam hal berbicara selama kelas berlangsung.

Sehubungan dengan pengamatan yang telah dilaksanakan, penulis menemukan beberapa hal yang dianggap penting terkait penelitian ini. Berdasarkan pengamatan yang penulis lakukan sebanyak 15 kali pertemuan didalam kelas, fokus penulis memang lebih banyak tertuju pada para siswa yang terindikasi memiliki karakteristik introvert berdasarkan tes sederhana yang sudah dilakukan oleh partner penulis, yaitu ahli psikologi dari Universitas Indonesia. Sekelompok siswa tersebut memang sedikit lebih pendiam dan kurang interaktif dibandingkan kelompok siswa ekstrovert, namun sebenarnya hal ini juga tidak sama seperti yang benar - benar kita bayangkan seperti misalnya mereka tidak melakukan interaksi sama sekali dari awal hingga akhir kelas. Penulis melihat mereka juga melakukan beberapa interaksi ketika para guru masuk lalu memulai kelas dan juga terhadap temanteman sekelas mereka. Namun memang, ketika para guru memberikan suatu topik, mereka tidak serta merta langsung memberikan tanggapan, penulis mengindikasi bahwa bukan berarti mereka tidak mengerti dengan topik tersebut, namun lebih pada keengganan mereka dalam mengembangkan dan mengeksplorasi topik pembicaraan tersebut. Melihat permasalahan tersebut, penulis melihat para guru mencoba beberapa kali menawarkan berbagai topic alternatif kepada para siswa dikelas dan semua topik tersebut merupakan hal- hal yang berkaitan erat dengan kehidupan sehari-hari. Jadi, para guru tersebut mencoba membawa topik yang berkaitan dengan realita sehari- hari ke dalam kelas speaking ini. Kemudian, mereka mengelompokkan siswanya kedalam beberapa kelompok dan memberikan semacam tugas dan permainan.

Terkait dengan kegiatan di beberapa kelas speaking ini, penulis menganalisa bahwa para siswa yang berkarakter introvert akan benar-benar merasa nyaman jika guru-gurunya memberikan lebih banyak kesempatan kepada mereka untuk berinteraksi antar siswa, karena sebenarnya mereka benar-benar membutuhkan hal- hal semacam itu. Lebih jauh, tindakan tersebut akan menjadi penting bagi para siswa yang berkarateristik introvert ini untuk dapat meningkatkan kemampuan speaking mereka. Tetapi masalah utamanya adalah mereka lebih sering merasa enggan menanggapi topik untuk dibicarakan secara langsung sehingga intensitas berbicara mereka dalam proses belajar mengajar memang terlalu minim. Para siswa ini juga sempat mengutarakan kepada penulis bahwa bahan yang diajarkan harus memuat lebih banyak kegiatan seperti games yang up to date yang bertujuan untuk meningkatkan interaksi antar sesama siswa dengan cara yang meyenangkan. Di sisi lain, para siswa yang berkarakter introvert tersebut memang benar-benar lebih menyukai sebuah pembelajaran melalui aktivitas daripada hanya mengkaji sebuah teori didalam kelas speaking. Karena itu, bahan ajar pun harus mewakili kompetensi pembelajaran kooperatif sebagaimana yang disarankan oleh para guru.

Berdasarkan bukti-bukti dari wawancara dan observasi yang telah dilaksanakan oleh penulis, terdapat tiga masalah utama yang dihadapi oleh para guru Bahasa Inggris dalam mengajar siswa berkarateristik introvert, khususnya dalam pelajaran speaking. Mereka adalah materi pembelajaran di kelas, interaksi antar siswa selama pembelajaran berlangsung, dan 
kesempatan berbicara untuk para siswanya. Terkait dengan masalah-masalah tersebut, para guru juga perlu mempersiapkan atau merancang bahan ajar berdasarkan karakteristik para siswanya yang dapat mengakomodir para siswanya yang berkarakteristik introvert agar dapat berinteraksi sebanyak mungkin selama proses belajar mengajar, sehingga para guru dapat memberikan tanggung jawab kepada semua siswa dalam bentuk kerja kelompok. Hal ini dinilai efektif sebagai sarana untuk meningkatkan kemampuan individu masingmasing siswa.

Sesuai dengan masalah dan strategi di atas, penulis menyimpulkan bahwa para guru dapat menggunakan metode pembelajaran kooperatif dalam merancang bahan ajar speaking kepada siswa. Sehingga, kelas yang memang didominasi oleh siswa berkarakteristik introvert juga dapat disejajarkan dengan kelas-kelas pelajaran speaking pada umumnya. Selain itu, Isjoni (2013) mengemukakan bahwa pembelajaran kooperatif adalah metode pengajaran dimana siswa bekerja sama dalam kelompok, biasanya dengan tujuan menyelesaikan tugas tertentu. Metode kooperatif ini dapat membantu siswa mengembangkan keterampilan kepemimpinan dan kemampuan untuk bekerja dengan orang lain sebagai sebuah tim. Namun, pada faktanya para siswa yang terlihat menonjol lebih sering ditempatkan dalam kelompok dengan siswa yang tidak terlalu menonjol dalam kelas. Hal ini seringkali dilakukan dengan tujuan agar siswa yang dianggap lebih berbakat dapat membantu orang teman-teman kelompoknya, baik secara langsung atau dengan contoh. Namun kelemahan dalam proses ini adalah siswa yang seringkali tampak menonjol dikelas kemungkinan tidak akan mempelajari sesuatu yang baru lagi, sedangkan siswa yang tampak kurang menonjol ini tidak memiliki kesempatan untuk mengembangkan kemampuannya.

Berdasarkan hal itu, Huda (2011), berpendapat bahwa terdapat lima perspektif teoritis tentang dasar pembelajaran kooperatif.

a) Perspektif Motivasional

Teori ini mengasumsikan bahwa pembelajaran kooperatif harus menempatkan reward kerja di dalam kelompok dan tujuan terstruktur. Berdasarkan teori ini, jika kegiatan pembelajaran dapat diterapkan, dapat menciptakan kondisi yang dapat membuat peserta didik berhasil dalam mencapai tujuan kegiatan belajar dalam kelompok mereka. Singkatnya, berdasarkan perspektif ini, semua peserta didik termotivasi untuk membantu pelajar lain untuk mencapai tujuan mereka bahkan mereka akan saling mendukung untuk mencapai tujuan.

b) Perspektif Kohesi Sosial

Perspektif ini adalah sedikit berbeda dari perspektif motivasional. Kedua perspektif ini lebih menekankan pada motivasi daripada kognitif dalam meningkatkan secara efektif pembelajaran kooperatif. Selain itu, Johnson dan Johnson di dalam Huda menjelaskan bahwa teori ini mengacu pada teori kemandirian sosial. Teori ini mengusulkan kita untuk berinteraksi dengan orang lain. Dalam pembelajaran kooperatif, salah satu elemen penting adalah umpan balik positif, semua anggota kelompok bergantung satu sama lain (Huda, 2011).

c) Perspektif Kognitif

Perspektif ini bertentangan dengan kedua perspektif sebelumnya, berfokus pada bagaimana manusia bertindak, berpikir, dan melanjutkan pembelajaran. Perspektif ini, yang lebih memandang tindakan antar siswa, akan meningkatkan prestasi belajar jika mereka mampu memproses informasi secara mental daripada perspektif motivasional.

d) Perspektif Pengembangan Kognitif

Perspektif ini didasarkan pada Jean Piagiet dan Vygotsky. Perspektif kognitif Piaget menekankan bahwa ketika peserta didik bekerja sama, kognitif sosial akan terjadi dan itu akan menciptakan ketidakseimbangan kognitif (disequilibrium kognitif). Ini akan mendorong peserta didik untuk meningkatkan pemikiran, ide-ide, dan kemampuan berbicara mereka.

e) Perspektif Kognitif Terelaborasi

O'Donnel dan O'Kelly (1994) telah mengembangkan perspektif ini. Perspektif ini menekankan bahwa elaborasi adalah latihan bagi pelajar, yang mampu meningkatkan aktivitas peserta didik dalam belajar. Perspektif ini mengasumsikan bahwa efek dari elaborasi adalah unsur yang paling penting dalam pembelajaran kooperatif. Elaborasi adalah berhubungan kuat dengan informasi baru. Salah satu teknik elaborasi yang efektif adalah penjelasan materi ajar kepada orang lain. Penelitian menunjukkan bahwa siswa akan belajar lebih dengan memberikan penjelasan kepada orang lain melalui teknik elaboratif daripada menggunakan bahan yang disiapkan.

Pada dasarnya, para ahli memiliki beberapa argumen yang berkaitan dengan pembelajaran kooperatif itu sendiri. Suprijono (2009) menyatakan bahwa pembelajaran kooperatif adalah sebuah konsep kerja kelompok, yang berada di bawah kontrol guru. Guru adalah sebagai pengarah, fasilitator, informan, dan penyedia. Dalam hal ini, guru merancang pemecahan masalah, yang berkaitan dengan masalah siswa.

Di sisi lain, Vygotsky melalui teori konstruktivisme sosialnya menekankan bahwa pengetahuan pelajar dibangun melalui sosial bersama, kegiatan di mana peserta didik berpikiran terbuka untuk bertukar pengetahuan dengan siswa lain. Jadi, dalam hal ini, pengalaman peserta didik adalah titik utama untuk pengembangan ide-ide siswa (Fosnot, 2013). Selanjutnya, menurut Suprijono, ada perbedaan konsep pembelajaran kooperatif antara Vygotsky dan Piaget. Menurut Piaget dalam konstruktivismenya mengatakan bahwa peserta didik membangun pengetahuan mereka dengan mengubah, mengatur, reorganisasi, dan menginformasikan latar belakang pengetahuan mereka. Di sisi lain, Vygotsky didalam Fosnot (2013) menekankan bahwa peserta didik membangun 
pengetahuan mereka melalui interaksi sosial karena pengetahuan mereka dipengaruhi oleh konteks budaya mereka yang melibatkan bahasa, keyakinan dan keahlian. Santrock (2014) dalam hal ini mendukung teori Vygotsky terkait dengan pembelajaran kooperatif. Ia menekankan bahwa pembelajaran kooperatif adalah aktivitas penguatan belajar melalui dialog interaktif. Selain itu, pembelajaran kooperatif didefinisikan sebagai belajar dasar sosial, sementara itu, dialog interaktif adalah kunci dari interaksi sosial.

Dukungan lain pada Vygotsky terhadap konsep pembelajaran kooperatifnya adalah makna dari kegiatan kelompok. Di antara para ahli adalah menurut Chaplin di dalam Suprijono (2009) yang mendefinisikan kelompok belajar adalah kumpulan individu yang memiliki beberapa karakteristik yang sama atau yang mengejar tujuan bersama. Dua orang atau lebih yang berinteraksi dengan cara apapun merupakan kelompok. Hal ini tidak perlu, namun, bagi anggota kelompok untuk berinteraksi secara langsung atau dengan cara tatap muka.

\section{PENUTUP}

Berdasarkan masalah, observasi, wawancara dan keterkaitannya dengan beberapa literatur, peneulis berpendapat bahwa pembelajaran kooperatif dapat menjadi solusi bagi siswa yang mempunyai karakteristik introvert yang mana gaya belajarnya terkesan lebih mandiri dan yang lebih memilih untuk bekerja sendiri. Dari temuan tersebut, penulis merekomendasikan semua pembaca terutama para guru Bahasa Inggris dan lebih khususnya lagi yang mengajar kelas speaking, bahwasanya mereka harus mempertimbangkan kondisi dan atmosfir kelas melalui pengetahuan karakteristik siswa-siswinya, karakter apa yang mendominasi dikelas, apakah itu ekstrovert ataupun introvert. Jika kelas speaking tersebut didominasi oleh para siswa introvert, pembelajaran kooperatif merupakan salah satu solusi dalam pengajaran speaking. Pada dasarnya penulis tidak mengatakan bahwa siswa introvert itu merupakan siswa yang kurang interaktif, mereka hanya perlu waktu dan kondisi yang tepat untuk berbicara, dikarenakan karakter yang mereka miliki membentuk pola model belajar yang tidak sama dengan siswa yang berkarakteristik ekstrovert. Dalam hal ini, para guru juga harus bertindak menjadi fasilitator bagi para siswanya. Dalam pembelajaran kooperatif, para siswa memiliki peluang yang besar untuk berbagi dan berbicara satu sama lain. Para guru juga harus menjadi pengendali selama kegiatan tersebut berlangsung. Jika nantinya para guru masih mendapatkan beberapa siswa yang kurang memiliki motivasi dalam berbicara, mereka tidak perlu mengubah strateginya, namun disarankan agar mereka dapat mengubah beberapa aktivitas dalam proses belajar mengajar berdasarkan apa yang telah mereka targetkan dengan tetap menggunakan pendekatan pembelajaran kooperatif.

\section{DAFTAR PUSTAKA}

Al-Jarf, R., 2012. Chapter Six Mobile Technology and Student Autonomy in Oral Skill Acquisition. Left to My Own Devices: Learner Autonomy and MobileAssisted Language Learning, 6, p.105

Al-Nassar, S.F. 2010. Reading strategy awareness of first year students. Student evaluation checklist University of Leeds, College of Education.

Bilbrough, N., 2007. Dialogue activities. Cambridge University Press.

Brown, G., Gillian, B. and Yule, G., 1999. Teaching the spoken language (Vol. 2). Cambridge: Cambridge University Press

Brown, H.D., 2000. Principles of language learning and teaching. Addison WesleyLongman. Inc. [AC]

Collie, J. and Stephen, S. 2006. Speaking Student's Book. Cambridge: Cambridge University Press

Fosnot, C.T., 2013. Constructivism: Theory, perspectives, and practice. New York: Teachers College Press

Friedman, H.S. and Schustack, M.W. eds., 2001. Readings in personality: Classic theories and modern research. Boston: Allyn and Bacon

Hakim, M.A.R., 2015. Experienced EFL teachers' challenges and strategies in teaching speaking for introvert students. European Journal of Social Sciences, 48(4), pp.437-446

Hakim, M.A.R., 2017. Teachers' Strategies in Teaching Speaking Lesson on Introvert Students in Madrasah Aliyah (MA) Ja-Alhaq Bengkulu. Madania: Jurnal Kajian Keislaman, 21(1), pp.23-30

Harmer, J., 2007. The practice of English language teaching. Harlow: Pearson Longman.

Huda, M., 2011. Cooperative learning (Vol. 113). Yogyakarta: Pustaka Pelajar

Isjoni, H., 2013. Cooperative Learning efektifitas pembelajaran kelompok. Bandung: Alfabeta

Leo, S., 2013. A Challenging Book to Practice Teaching in English. Yogyakarta: Penerbit Andi

Maynard, D.M., 2013. Eysenck, Hans Jürgen. The Encyclopedia of Cross - Cultural Psychology,2, pp.530-533

Murray, D.E. and Christison, M., 2010. What English language teachers need to know: understanding learning, Vol 1. New York: Rotledge

Nurmayasari, E., \& Rahmawati, S. 2016. A Comparative Study between Extroverted and Introverted Students and Their Speaking Ability. English Journal, 15(2), 20-29 
DOI : 10.26740/jp.v4n1.p49--58

O'Donnell, A.M. and O'Kelly, J., 1994. Learning from peers: Beyond the rhetoric of positive results. Educational Psychology Review, 6(4), pp.321-349

Rauch, J., 2003. Caring for your introvert. The Atlantic, March

Santrock, J.W. 2014. Educational Psychology. New York: McGraw Hill.Sudrajat, A., 2011. Kurikulum dan Pembelajaran dalam Paradigma Baru. Yogyakarta: Paramitra Publishing

Sunartyo, N., 2008. Kupas Tuntas Psikotes. Jogjakarta: Diva Press

Suprijono, A., 2009. Cooperative learning: teori \& aplikasi PAIKEM. Yogyakarta: Pustaka Pelajar

Thornbury, S., 2005. How to teach speaking. Longman

Tillit, B. and Bruder, M.N., 1999. Speaking naturally. Cambridge: Cambridge Univer

Wardani, K., 2010, November. Peran Guru Dalam Pendidikan Karakter Menurut Konsep Pendidikan Ki Hadjar Dewantara. In Proceeding of The 4th International Conference on Teacher Education; Join Conference UPI \&UPSI (pp. 8-10)

Ya-Ni, Z., 2007. Communication strategies and foreign language learning. US-China Foreign Language, 5 (4), pp.43-48. 